\title{
Challanges sustainable coastal tourism on Panjang Island
}

\begin{abstract}
The development of coastal tourism on Panjang Island greatly helped the socio-cultural development and socio-economic growth of coastal communities. On the one hand, the development on the island is very rapid, both in terms of industry and in terms of the business of coastal reclamation for the construction of hotels and housing with coastal nuances. As a result, environmental degradation has occurred which has prevented environmental-based coastal tourism. On the other hand, there is a decline in biodiversity growth. This study explores the challenges sustainable coastal tourism management efforts. In addition, this study will also look for factors that determine the business that helped efforts to improve the standard of living of coastal communities living in coastal areas.
\end{abstract}

Volume 8 Issue 5 - 2019

Hengky SH
Universitas Bina Darma, Shine Institute, Indonesia

Correspondence: Hengky SH, Universitas Bina Darma, Kent Polytechnic, Shine Institute, Indonesia, Email hengky_halim@yahoo.com.au

Received: August 28, 2019| Published: October 30, 2019

Keywords: sustainable coastal-tourism, Panjang Island, coastal communities

\section{Introduction}

Based on the Spatial Planning Regional Regulation, a massive exploitation permit issued from the coast, which is located adjacent to Panjang Island. This causes the coastal islands to have decreased the quality of the coastal environment, especially those that is a result of pollution and environmental damage from sand mining. As a result, environmental degradation and landscape changes occur. These sand mining activities in areas that are technically, ecologically and socially, can cause environmental damage or harm the surrounding community.

The coastal development model for decades has exploited its abundant natural resources to feed a population that is now bubbling with 260 million and triggering an economy that is included in the world's top 20. While, this forest offers several large swathes of the world's last tropical rainforest, it also flattens it at a rate that exceeds deforestation. Recognizing that its natural resources cannot sustain the current pace of development, the government is now ushering in a new development blueprint that tries to remain in this ecological carrying capacity.

Development in the long island region has been carried out with the reality showing that various patterns of the forms of development that have been implemented have caused problems with the form of development impacts on the form of environmental damage. The process of development in various sectors will certainly have a new impact on the environment, on the other hand the level of concern from the community that is felt to be lacking in environmental issues will also aggravate the occurrence of these environmental impacts.

The rapid growth of the economy and industry on the island has had a positive impact on the form of economic growth and labor absorption, also causing inevitable negative impacts, especially seen from the environmental aspect. The impact is in the form of increasing pressure on the preservation of natural resources and the environment. Development is not enough for us to look at its economic values. There are environmental values related to ecosystems and biodiversity, whose value is greater than the economic values that felt directly.

\section{Identification several problems}

Several problems identified the condition of a small Island (such as Panjang island) included:

1. Decreasing ecosystem function caused by factors of regional function transferred, over exploration, and weak institutional factors. In addition, there is erosion, sedimentation, pollution, natural phenomena / natural disasters. ${ }^{1}$

2. Decrease in ecosystem benefits that include ecological, economic and social, both direct and indirectly. ${ }^{2}$

3. Conflict of utilization in the coastal area between the community and the environment where most of the people in the coastal area still utilize the existence of a less sustainable ecosystem in the form of logging activities, and the use of a fish's bombs. ${ }^{2-4}$

According to the Final Report of the Banten Potential Compilation and Mapping Project, the total potential for the Mangrove Forest in the Province is 2,214.45ha (not including the Thousand Islands area). According to the data, total potential of Mangrove Forests in the region had listed as only 721.08 hectares. This means that within five years there has been a decline in mangrove forests to reach $\pm 60 \% .{ }^{5}$

Abovementioned, the purpose of this study is to explore the challenges of sustainable coastal tourism management efforts in the Long Islands.

\section{Literature Review}

Mangrove forests are part of the natural and human cultural heritage that supports the economy, industry, ecology, socio-economy and culture of the country. The people living around the land depend on the forest's natural resources. As a result, the mangrove forest is threatened with growth. ${ }^{6}$ The UN member states propose a Sustainable Development program in 2014, which can facilitate the integration of cross-sectoral policies. Beyond the program produces, it integrates thematic, policy and socio-economic fields at various appropriate scales. ${ }^{7}$ 
Concerns about sea level rise and nature conservation have caused a shift from hard engineering to a more sustainable management approach. Managed Realignment is increasingly popular with Europe: the creation of more intertidal habitats, and improved floodrisk management. Several independent studies have shown: reduced biodiversity; development of new salty swamps at the expense of existing habitats; poor provision of ecosystem services; and lack of understanding of sediment effects. ${ }^{8}$

The dynamics and uncertainty in coastal ecosystems were not disrupte by stability. Managers can build appropriate baselines that cover biodiversity and ecological integrity to maintain ecosystem health and the reliability of urban industrial systems. Ecosystem restoration and rehabilitation illustrate practices that restore the ecosystem to optimal biological integrity. While, it more humandominated estuary health to manage natural processes and functions. Control of contaminant sources, appropriate sediments and water quality, and human efforts to maintain the commercial activities and welfare of biota that support species adapted together with human presence. ${ }^{9}$

The fastest-growing sector of the tourism industry ecotourism offers tourism companies and Third World destinations together the prospect of leveraging the comparative advantages of these countries in terms of the unspoiled natural environment. By definition, such development must benefit the destination on a small scale, local involvement with fewer negative impacts. Opportunities for these countries to increase their development potential by utilizing their natural resources without, at the same time, destroying them cannot be deny. What is important, however, is the recognition that, without adequate understanding of the underlying factors and careful planning and management, ecotourism can cover unsustainable aspects. ${ }^{10}$

The coastal zone is experiencing rapid development and increasing storms and floods that placed coastal communities at high security risks. The coastal areas of the islands present various properties that had been exploiting by humans. Continuous differentiation in the utilization of coastal zones causes conflict of supporting ecosystems with human activities. Various pressures and climate change, population and tourism, port development. All of these factors influence the pattern of sustainable use of coastal resources. ${ }^{11}$

Meta-analysis revealed that coral reefs provide substantial protection against natural hazards by reducing wave energy by an average of $97 \%$. The reef peaks at removing most of this energy $(86 \%)$. Coastal communities receive risk reduction benefits of coral reefs or bear the costs of mitigating hazards and adaptation, as well as coral reefs are degraded. Coral reefs can provide the benefits of wave attenuation comparable to artificial defenses such as breakwaters. ${ }^{12}$

Meta-analysis revealed that coral reefs provide substantial protection against natural hazards by reducing wave energy by an average of $97 \%$. The reef peaks at removing most of this energy $(86 \%)$. Coastal communities receive risk reduction benefits of coral reefs or bear the costs of mitigating hazards and adaptation, as well as coral reefs are degraded. Coral reefs can provide the benefits of wave attenuation comparable to artificial defenses such as breakwaters. ${ }^{13}$ The difference between the prevailing economic model and the sustainable use of resources seems to be insurmountable for a long time. On the other hand, many radicalized debates, nature-based solutions can offer a transition path with realistic and gradual steps towards a naturebased sustainable economy, providing socio-economic benefits, providing jobs, and low-carbon technological innovation. ${ }^{14,15}$

Problems of land-water resources and environmental quality are increasing with rapid economic development in coastal areas. The problems facing the region include reduction of arable land, land degradation, high percentage of land built, deteriorating water quality, and increased biodiversity. Sustainable development aims to control areas of cultivated land and enforce the remediation of polluted water environments. Besides that, controlling non-point pollution and strengthening ecological security and controlling multi-polution. ${ }^{14,16}$.

\section{Methodology}

This study was conducted on Pulau Panjang (Table 1) for 12 months from December 2017 involving at least 160 of the 250 respondents that responded to the questionnaire which included increasing economic development, reduction of land degradation, deteriorating water quality, increased biodiversity, severe air pollution. ${ }^{14,16,17}$ All data are tabulated using SAS contextual Analysis software and there are 5 stages of data exploration: (1) Collection, (2) Transformation, (3) Text parsing, (4) Filtering and (5) Mining. The tabulation results expressed by the value of $\mathrm{K}$ (Kappa) which is the result of a consistent comparison of data frequencies. Data is obtained using content analysis ${ }^{18}$ which includes 6 steps to produce Kappa values $(=\mathrm{K}) . \mathrm{K}<6$ means moderate. $\mathrm{K}>6$ means substantial. ${ }^{19}$ These steps $^{20}$ are: (1) exploration of respondent's decisions; (2) parameters decided based on the concept of sustainable tourism; (3) Consistency of the decision of each parameter based on the concept; (4) suitable parameter decisions based on sub-concepts; (5) recurring frequency calculation of each parameter according to the sub-concept; and (6) results analysis. (Figure 1)

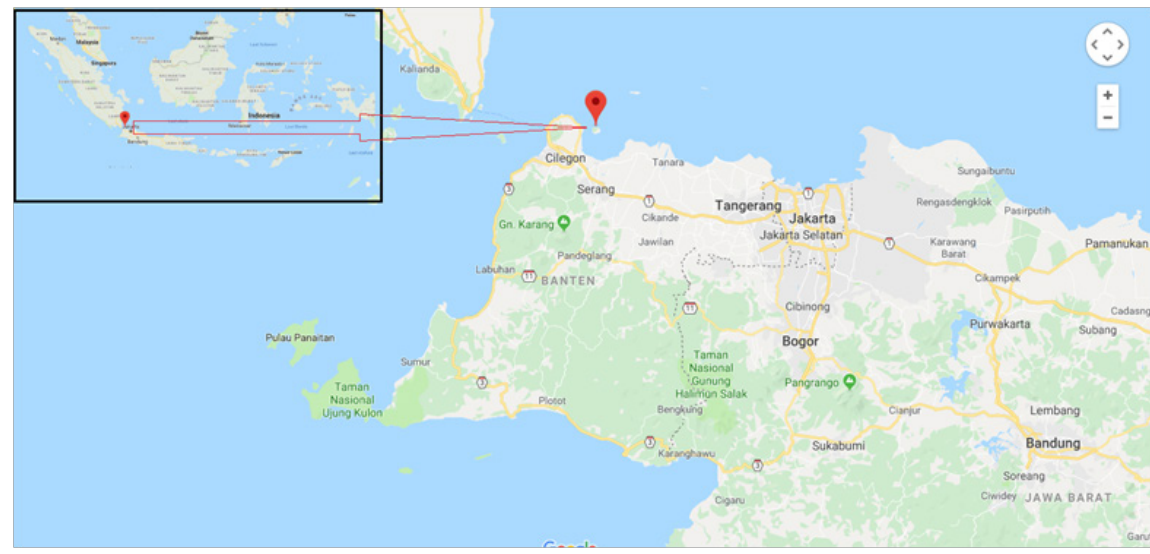

Figure I Panjang Island. 


\section{Result and discussion}

The SAS tabulation results (Table 1) indicate that the performance of the coastal tourism in Panjang Island (CTPI) is in critical condition ( $\mathrm{K}=0.5966$-moderates). The indicator is that the effort to increase the supply of biodiversity and seawater quality is getting worse due to the efforts of coastal reclamation and sea sand mining. ${ }^{21,22}$ Coastal economic development consists of fisheries, seaweed farming and tourism. The fishing business in the island has been operating in 32 years as a salted anchovy artisan marketed to meet the demand for salted anchovy. They received raw material supplies of nearby anglers, and anchovy sellers. The fish processed from Cilegon City, Serang Regency and City, and Jakarta. Sometimes, they receive requests for one of the exporters of salted fish in the Surabaya region for export to Japan. They have tried for decades. Right now, they are starting to feel the results. They used to harvest it every two day at least 600kilograms to sell outside. They produce several types of salted anchovy, at normal times in two days. They are usually able to produce salted anchovy up to one ton per angler. Acting Head of Pulo Panjang Village, he is supportive citizens to develop their business as salted fish producers. He also encouraged local governments to support their citizens that had been able to produce salted anchovy for the quality of exports abroad. Most coastal communities do work as anglers. Some of them also develop businesses as producers of salted anchovy. This performance needs to be the pride in the government. A part of the anchovy is exported to overseas. ${ }^{22}$

Table I Existing performance of coastal tourism in Panjang Island

\begin{tabular}{lll}
\hline $\begin{array}{l}\text { Sustainable coastal tourism on } \\
\text { Panjang Island }\end{array}$ & Value & \% Freq \\
\hline increasing economic development & 33 & 0,3143 \\
reduction land degradation & 25 & 0,2381 \\
deteriorating water quality & 24 & 0,2286 \\
increased biodiversity & 23 & 0,2190 \\
\hline Kappa = K = & 0,5966 & \\
\hline
\end{tabular}

Further tabulation (Table 2) clearly shows some challenges to maintaining sustainable coastal tourism efforts needed to reduce coastal degradation and improve final quality. These efforts are to increase biodiversity.

Table 2 Sustainable challenges of coastal tourism in Panjang Island

\begin{tabular}{lll}
\hline $\begin{array}{l}\text { Sustainable coastal tourism on } \\
\text { Panjang Island }\end{array}$ & Value & \% Freq \\
\hline increasing economic development & 31 & 0,254 I \\
reduction land degradation & 30 & 0,2459 \\
deteriorating water quality & 32 & 0,2623 \\
increased biodiversity & 29 & 0,2377 \\
\hline Kappa $=$ K = & 0,6932 &
\end{tabular}

Furthermore, seaweed cultivation is one of the potential livelihoods in the coastal area of Panjang islands. Therefore, this activity must be manage optimally from various dimensions including environmental, technological, social and economic dimensions. The results showed that the most dominant attributes of the actual conditions on the strength component were the suitability of the waters for seaweed cultivation and waters protection. While, the most dominant component of weakness is the limited capital and means of drying seaweed. The most dominant component of opportunity is the increase in income of farmers and the potential for the seaweed market. The most dominant threats are heavy metal polluters and domestic waste pollutants. This study shows that the strategy for managing the sustainability of seaweed farming on Panjang Island done. It would increasing cooperation between the processing industry, fostering and supervising the selection of materials and seaweed cultivation techniques in accordance with Indonesian National Standards. Besides, it improving post-harvest processing, strengthening coaching and technical guidance for farmers in choosing high-quality seaweed seeds and strengthening policies regarding the availability of business capital guarantees through the development of a capital lending system with easy terms and low interest rates for farmers. ${ }^{16}$

On the other hand, economic development in the context of coastal tourism on Panjang Island shaped as a less dense residential island. That is the first impression of tourists' set foot of the island in Banten Bay, Java Sea. The area around Panjang Island is an area that has many tourism assets. One interesting tourism, namely the existence of outer islands that have the potential to be developed. The beach on Panjang Island is still untouched to date. This is due to the limited management budget and the need for innovation. Tourism in the island should be develope. By developing, it will be other income for the region for its development. It was necessary to do it by cooperating with entrepreneurs. In terms of arrangement, the central government may not take its own policies. Determining the policy that had regions needed to be talked to Hasanudin.

Another challenge is that there are no hotels or inns in Pulau Panjang. Tourists can hire local residents' houses or Camping. The most important, do not forget to bring mosquito repellent lotion. From the city of Jakarta, weekends and enjoying a long night at Pulau Panjang can be an alternative. The existence of Pulau Panjang, it must continue to be protected, maintained, improved the quality of its value and diversity, and maintained its ecosystem. This is to ensure the existence, availability and continuity of coastal resources in the small island of Pulu. Pulau Panjang is one of the small island's conservation tourist areas. It located on the north coast of the island of Java. This is as determined by the Decree of the Jepara Regent regarding the Reserve of the Pulau Panjang Small Island Park area. The area of Pulau Panjang now, between 21.1 hectares and filled with coastal vegetation, such as mangroves, pine, lagoons, pandanus, and sea girdle.

The central part of the island is a tropical forest structured with large and tall trees towering interspersed with shrubs and shrubs. This place is also a place for seabirds to breed. There are also a few plantations of tooth trees, which are quite rare. Here grows the types of Setigi and Bayo trees that they must keep guarding. In addition to tracking, tourists can also do Syekh Abu Bakr Bin Yahya's religious tour of the tomb, which is one of the spreaders of Islam in Jepara. Not a few visitors come to Panjang Island to make a pilgrimage to the tomb Muharam in 2018.

Pulau Panjang is a populated island. It has a slopping topography of mainland islands, and over-grown with mangroves in almost all its islands. Pulau Panjang is the most extensive island in the region.

It also very close to urban areas. Especially, the industrial areas in Banten Province. In addition, access to Pulau Panjang is also quite easy, one of which is from the East Cilegon area, precisely by crossing from the Cikubang area with a small boat for only about 30 minutes. 
Facilities and infrastructure are also quite complete as land areas are relatively advanced. So that, the lives of people in this area are generally like the people in the urban areas in general.

Given that, Panjang Island is closest to the industrial area in Banten Province. The waters of Pulau Panjang also very affected by various activities in the land area (industry) that are in front of Pulau Panjang. On the other hand in the land area adjacent to Panjang island there are various large-scale industrial activities both national and industrial industries which are included in foreign investment, which operate in various types of industries. These industries, which are located adjacent to Pulau Panjang, generally do not only sell locally, but also sell nationally (between islands), export, and import. Therefore, the density of traffic activities of materials and the traffic of the products they produce, has forced these industries to carry out efficiency in various fields. One of them is the efficiency of the transportation activities mentioned above. Therefore, these industries eventually make their own ports or in other words, every major industry makes a terminal for its own sake.

The next challenge is environmental degradation, with the construction of terminal activities for its own sake and reclamation activities in the industrial area, which ultimately lead to various problems. These problems include disturbing or even removing ecosystems in the location where the terminal built or in the reclaimed area. On the other hand, the development also results in changes in current and wave patterns. This condition disturbs the shipping of anglers. The most feared impact is the potential for abrasion in other small island areas. Therefore, the existence of terminal activities and reclamation in the industrial area of Banten Province this must be study for carrying capacity. So as not to disturb the existence of Panjang Island and other small islands. Furthermore, these activities should not interfere with fisheries activities and do not significantly interfere with ecosystems in the region.

In the midst of the solitude of the island, there were unrest in the residents of the planned eviction of their settlements. A corporation has released it almost parted from the land on the island covering an area of 820 hectares. The topography of Pulau Panjang is mostly low land with a slope of $0-15 \%$ and a height of $0-2$ meters above sea level. Land-use patterns in general are coconut plantations, settlements, swamp forests, shrubs and vacant land. The condition of the land is not too fertile and there are many creeping shrubs in the interior.

Based on the sediment surface map of the sea floor issued by P3GL, the area around Pulau Panjang contains a lot of silt. Based on the results of the study in 2015, the components that spread evenly in the eastern and western parts of the island were silt units, which had a dominant distribution, which was more than $50 \%$. The rest are silt sand units and sandy clay units that are not more than $50 \%$ of the total study area.

Moreover, there is massive reclamation in the region, environmental degradation occurs. The news of the merging of Long Island with the island of Java in Serang Regency has been widely distributed among the Bojonegara community. The reclamation effort to reach Panjang Island caused many mountains to continue to be dredge. the sea was deteriorated as a borderless island. Thet more important to it is the impact on the community that is greater than what is due to the impact on the activity. One of the anglers in the Wadas base, Bojonegara, which is a long distance away from its base, which had surrounded by cross reclamationn.

The last challenge, by improving coral reef biodiversity and fish, the beauty of diving tourism is more attractive. This beach arranged deliberately. So that, it can attract them and avoiding abrasion, views of clean white sand beaches, and the stretch of coral reefs. These efforts to improve biodiversity carried out by making several spots of mangrove forests and shallow corals. Various types of fish can be found on this spot such as Mangrove Jack, Kuwe (Giant Trevally), Barracuda, Grouper, Gutter, Baramundi to Chopsticks.

In addition to enjoying the sunset and sunrise from the beach that is full of coral rocks and not sandy, tourists can also swim on the shallow and clear beach. So that, small fish can be seen. They must be careful about sea urchins. For snorkeling, tourists can hire a fishing boat and ask to delivere to charming underwater spots. Not to forget, they can fish or explore mangrove forests and their nurseries, ornamental fish and shipbuilding. For whom want tranquility, it is certainly suitable for spending their time and have a leisure in this island.

\section{Conclusion}

Based on the sustainable coastal tourism, this study found several challenges to sustaining their programs:

1. The economic change in the development of coastal communities due to land conversion and environmental degradation. To maintain economic performance, environmental conservation support is needed

2. Because of environmental degradation, integrated efforts needed from the local government to coastal communities to reduce the negative environmental impacts by involving stakeholders.

3. The inevitable challenge is decreasing the quality of water that is suitable for consumption. This happens because there are so many reclamation activities and land conversion functions.

4. Because of over-exploitation, efforts needed to increase biodiversity to support coastal tourism activities in a sustainable manner. So that, coastal tourism can be supported by diving tourism to enjoy the beauty of lam and other biota.

5. Further research needed on efforts to develop cultural tourism and culinary tourism to enliven coastal tourism in the future.

\section{Acknowledgement}

The author intends to express thousands of thanks to the reviewers that have contributed to sharpen this paper so that it published.

\section{Funding}

None.

\section{Conflicts of interest}

The author declares that there are no conflicts of interest.

\section{References}

1. Feng YX, Luo GP, Li CF, et al. Dynamics of Ecosystem Service Value Caused by Land use Changes in Manas River of Xinjiang, China. Int $J$ Environ Res. 2012;6(2):499-508.

2. B Cluer, C Thorne. A stream evolution model integrating habitat and ecosystem benefits. River Res Appl. 2014;30(2):135-154.

3. P Salmi. Constraints and Opportunities for Small-Scale Fishing Livelihoods in a Post-Productivist Coastal Setting. Sociol Ruralis. 2015;55(3):258-274

4. Halim HS. Scrutinizing Coastal Ecotourism in Gili Trawangan, Indonesia. Int J Mar Sci. 2017. 
5. Ministry of National Development Planning. Marine Development in the 2015-2019 National Medium-Term Development Plan. www. bappenas.go.id. 2014 .

6. Islam SN. An analysis of the damages of Chakoria Sundarban mangrove wetlands and consequences on community livelihoods in south east coast of Bangladesh. Int J Environ Sustain Dev. 2014;13(2):153.

7. D Le Blanc. Towards Integration at Last? The Sustainable Development Goals as a Network of Targets. Sustain. 2015;23:(3):176-187.

8. Esteves LS. Is managed realignment a sustainable long-term coastal management approach? J Coast Res. 2013;65(1):933-938.

9. Weinstein MP, Reed DJ. Sustainable Coastal Development: The Dual Mandate and a Recommendation for \&quot; Commerce Managed Areas\&quot. Restor Ecol. 2005;13(1):174-182.

10. Cater E. Ecotourism in the third world: problems for sustainable tourism development. Tour Manag. 1993;14(2):85-90.

11. Turner R K, Lorenzoni I, Beaumont N, et al. Coastal Management for Sustainable Development: Analysing Environmental and SocioEconomic Changes on the UK Coast. Geogr J. 1998;164(3):269.

12. Ferrario F, Beck MW, Storlazzi CD, et al. The effectiveness of coral reefs for coastal hazard risk reduction and adaptation. Nat Commun. 2014;5(1):3794.

13. Van Dongeren A. RISC-KIT: Resilience-Increasing Strategies for Coasts - toolkit. J Coast Res. 2014;70:366-371.
14. Maes J, Jacobs S. Nature-Based Solutions for Europe's Sustainable Development. Conserv Lett. 2017;10(1):121-124.

15. Zarei M, Mohammadian A, Ghasemi R, et al. Internet of things in industries: a survey for sustainable development. Int J Innov Sustain Dev. 2016;10(4)419.

16. Zhao Q G. Resource and environmental quality changes and adjustment principles for sustainable development in rapidly developing coastal region of southeastern China. 2001.

17. Ojanen V, Ahonen $\mathrm{T}$, Reunanen $\mathrm{M}$, et al. Towards availability and sustainability in customer value assessment of asset management services. Int J Innov Sustain Dev. 2012(6)4:368.

18. Vaismoradi M, Turunen H, Bondas T. Content analysis and thematic analysis: Implications for conducting a qualitative descriptive study. Nurs Health Sci. 2013;15(3):398-405.

19. Kraemer HC. Kappa Coefficient. In: Wiley Stats Ref: Stat. Reference Online, Chichester, UK: John Wiley \& Sons, Ltd, 2015, p. 1-4.

20. Chen G, Faris P, Hemmelgarn B, et al. Measuring agreement of administrative data with chart data using prevalence unadjusted and adjusted kappa. BMC Med Res Methodol. 2009;9(1)5.

21. Dinwoodie J, Tuck S, Knowles H, et al. Sustainable Development of Maritime Operations in Ports Bus. Strateg Environ. 2012;21(2) p. 111126.

22. Tessler ZD et al., Environmental Science. Profiling risk and sustainability in coastal deltas of the world. Science. 2015;349(6248) p. 638-643. 